УДК 373.24:37.018.1

DOI:

Олена Квас, доктор педагогічних наук, професор кафедри загальної та соиіальної педагогіки Львівського національного університету імені Івана Франка Марія Шира, магістр кафедри початкової та дошкільної освіти Львівського національного університету імені Івана Франка

\title{
ПЕДАГОГІЧНІ УМОВИ ФОРМУВАННЯ ЗДОРОВОЇ ОСОБИСТОСТІ ДИТИНИ ДОШКІЛЬНИКА У ПРОЦЕСІ ВЗАЕМОДІЇ ЗАКЛАДУ ДОШКІЛЬНОЇ ОСВІТИ І СІМ’ї
}

Стаття присвячена розгляду проблеми формування здорової особистості дитини дошкільного віку у процесі взаємодї̈ закладу дошкільної освіти $і$ сім'̈. Обгрунтовується, щзо реалізація педагогічних умов, а саме: підвищення компетентності вихователів щуодо формування здорової особистості дитини; вироблення у вихованців звичок здоров 'язбережувальної поведінки на основі формування у них позитивного ставлення до ї̈ норм і правил, щзо визначає їхню життєву позицію у взаємодії з довкіллям сприятимуть зростанню рівнів сформованості здорової особистості дитини дошкільного віку у проиесі взаємодї̈ закладу дошкільноӥ освіти і сім $\dddot{\imath}$.

Ключові слова: здорова особистість; дитина дошкільник; взаємодія; педагогічні умови; формування. תim. 8.

Olena Kvas, Doctor of Sciences (Pedagogy), Professor of the General and Social Pedagogy Department Lviv Ivan Franko National University Mariya Shyra, Master of the Primary and Preschool Education Department Lviv Ivan Franko National University

\section{PEDAGOGICAL CONDITIONS OFTHE FORMATION OFA HEALTHY PERSONALITY OF A PRE-SCHOOL CHILD IN THE PROCESS OF INTERACTION BETWEEN THE PRESCHOOL EDUCATIONAL ESTABLISHMENT AND THE FAMILY}

The article is devoted to the consideration of the problem of formation of healthy personality of a child of preschool age in the process of interaction between the institution of the preschool education and the family. The analysis of the pedagogical literature shows that in the aspect of work of the institution of pre-school education with the family, two problems were analyzed in more details: psychological and pedagogical education of parents with the aim to increase their level of pedagogical awareness in this direction and studying the family and establishing contacts with its members for the purpose to approve the the educational effects on the child.

The detailed consideration of the problem of the forming a healthy personality of the child made it possible to determine the dependence of this process on the attitude of parents towards the physical development of children and observance of a healthy lifestyle by all its members; from the organization of health care preservation of children in preschool educational institutions, the creation of the conditions for the health regime.

It is substantiated that the implementation of the pedagogical conditions, like: raising the competence of educators in the formation of a healthy personality of a child; the development of the habits to take care about your health on the basis of the formation of their positive attitude to its norms and rules that determine their vital position in interaction with the environment will contribute to the growth of the levels of the formation of a healthy personality of a child in preschool age in the process of the interaction between the institution of the preschool education and the family.

It is proved that these forms of work with parents are optimal, taking into account the individual differences of each family, family traditions, and the interests of the family in the issues of strengthening the health of the children.

Keywords: healthy personality; a preschooler; an interaction; pedagogical conditions.

П остановка проблеми. Думка про здорову дитину проходить як головний лейтмотив у чинних державних документах, численних програмах навчання й виховання дітей дошкільного віку. Основні підходи до збереження і зміцнення здоров'я дітей визначено в законах України "Про освіту”, “Про дошкільну освіту”, “Про охорону дитинства”, Національній стратегії розвитку освіти до 2021 року, Державній національній програмі “Діти України", Базовому компоненті дошкільної освіти та ін. Водночас існуе суперечність між суспільними вимогами щодо збереження та зміцнення здоров'я дитини та реальним 


\section{ПЕДАГОГІЧНІ УМОВИ ФОРМУВАННЯЗДОРОВОЇ ОСОБИСТОСТІ ДИТИНИ ДОШКІЛЬНИКА У ПРОЦЕСІ ВЗАЕМОДІЇЗАКЛАДУ ДОШКІЛЬНОЇ ОСВІТИ І СІМ'Ї}

незадовільним станом здоров'я підростаючого покоління.

В умовах реформування дошкільної освіти одним із основних їі завдань $є$ виховання гармонійно розвинутої, довершеної, здорової особистості, здатної повною мірою реалізувати свої фізичні, інтелектуальні, моральні та духовні можливості.

Питання охорони, збереження й зміцнення здоров'я дітей розкрито в працях Г. Бєлєнької, Е. Вільчковського, Н. Денисенко, Л. Лохвицької та ін. Щодо формування здорової особистості в період дошкільного дитинства актуальні дослідження I. Беха, О. Кононко, Л. Сварковської.

Проте поза увагою залишилося питання, як заклад дошкільної освіти має взаємодіяти 3 сім'ями вихованців, щоб забезпечити формування здорової особистості дитини.

Мета статті - окреслити педагогічні умови формування здорової особистості дитини дошкільника у процесі взаємодії закладу дошкільної освіти і сім'ї.

Аналіз останніх досліджень і публікацій. Проблему формування здорового способу життя у дітей старшого дошкільного віку досліджували: С. Юрочкіна (педагогічні засади валеологічного виховання) [8], Т. Андрющенко (формування здоров'язбережувальної компетеності в дітей дошкільного віку) [1], Н. Семенова (формування здорової особистості дитини 6-го року життя) [6], Т. Бабюк (наступність у вихованні здорового способу життя старших дошкільників і молодших школярів) [2], С. Бабюк (педагогічні умови фізичного виховання дітей старшого дошкільного віку у взаємодії дошкільного навчального закладу і сім’і), Л. Сварковська (формування у дітей 5-6 років мотивації до занять фізичною культурою) [5], О. Філоненко (виховання культури поведінки у дітей $6-7$ років) [7], С. Замрозевич (формування готовності дітей старшого дошкільного віку до навчання в школі у процесі фізичного виховання), О. Іванашко (психологічний аналіз усвідомлення здорового способу життя дітьми дошкільного віку, Л. Карнаух (виховання безпечної поведінки дітей дошкільного віку у соціальному середовищі), Н. Лісневська (педагогічні умови створення здоров'язберігаючого середовища у дошкільному навчальному закладі).

Для вирішення проблем здоров'я та формування здорового способу життя дошкільників розроблено авторські програми: комплексну програму розвитку навчання та виховання дітей дошкільного віку “Соняшник” (Л. Калуська), “Малятко-здоров’ятко”(Н. Денисенко,
В. Музирова, Л. Шевцова), “Про себе треба знати, про себе треба дбати” (Л. Лохвицька).

Аналіз наукових досліджень щодо формування здорового способу життя у дітей дошкільного віку дозволив узагальнити, що формування здорової особистості дитини забезпечується у процесі соціалізації дитини, під час іiї життєвої практики та реалізується через цілеспрямований і усвідомлений процес творення дитиною власної системи життєдіяльності, основа якої відповідальне ставлення до здоров'я.

Виклад основного матеріалу. Аналіз психолого-педагогічної літератури (С. Ладивір, Л. Лохвицька, Н. Семенова та ін.) показує, що в аспекті роботи закладу дошкільної освіти з сім'єю більш докладно досліджено дві проблеми: психолого-педагогічна просвіта батьків $з$ метою підвищення рівня їх педагогічної обізнаності в цьому напрямку і вивчення сім'ї та становлення контактів 3 їі членами 3 метою погодження виховних впливів на дитину.

Це визначає важливе завдання - визначити i дослідити педагогічні умови, які можуть бути реалізовані для забезпечення ефективної взаємодії закладу дошкільної освіти 3 сім'єю щодо формування здорової особистості дитини дошкільника.

У лексикографічних джерелах термін “педагогічна умова” трактується як “певна обставина чи обстановка, яка впливає (прискорює чи гальмує) на формування та розвиток педагогічних явищ, процесів, систем, якостей особистості”.

Детальний розгляд проблеми формування здорової особистості дитини дошкільника дав змогу виявити залежність цього процесу від ставлення батьків до фізичного розвитку дітей та дотримання в родині здорового способу життя усіма іiі членами; від організації вихователями здоров'язбережувальної діяльності дітей у закладу дошкільної освіти, створення умов для оздоровчого режиму. Встановлено відсутність пріоритетності здоров'я, забезпечення лише санітарно-гігієнічних умов та нормування рухових навичок і фізичних якостей дітей, що не забезпечує формування здорової особистості дитини та вимагає реалізації відповідних педагогічних умов у навчально-виховному процесі закладу дошкільної освіти.

У зв'язку з цим було сформульовано припущення про те, що формування здорової особистості дитини буде ефективним за реалізації таких педагогічних умов:

- підвищення компетентності вихователів щодо формування здорової особистості дитини; 


\section{ПЕДАГОГІЧНІ УМОВИ ФОРМУВАННЯЗДОРОВОЇ ОСОБИСТОСТІ ДИТИНИ ДОШКІЛЬНИКА}

У ПРОЦЕСІ ВЗАЄМОДІЇ ЗАКЛАДУ ДОШКІЛЬНОЇ ОСВТТИ ССМ'Ї

- вироблення у вихованців навичок здоров'язбережувальної поведінки на основі формування у них позитивного ставлення до іiі норм і правил, що визначає їхню життєву позицію у взаємодії з довкіллям.

Перша педагогічна умова - підвищення компетентності вихователів щодо формування здорової особистості дитини - обумовлюється тим, що педагог як суб'єкт педагогічного процесу забезпечує фізичний та психічний розвиток дітей, формуючи в них навички здоров' язбережувальної поведінки. Водночас, діяльність дітей змінює якість діяльності педагога, спонукаючи його до запровадження нового змісту, нових форм і методів виховання та навчання, які максимально відповідають індивідуальним особливостям дітей. У результаті відбувається не тільки розвиток кожної дитини, але й професійне й особистісне зростання педагога. Орієнтування вихователя на особистість дитини відображають його комунікативні вміння: слухати дитину, правильно сприймати ï індивідуальність, відмовитися від впливу і перейти до оптимальної взаємодії, організовувати спілкування не "від себе" а “від дітей”. Професійне вдосконалення вихователів закладів дошкільної освіти тісно вимагає самоаналізу їхньої діяльності, усвідомлення власних потенційних можливостей та труднощів. Ефективність аналізу і самоаналізу визначається наявністю у педагогів умінь: вивчати дитяче товариство і кожну особистість; діагностувати розвиток дітей; аналізувати конкретні педагогічні ситуації; вивчати й узагальнювати власний та передовий педагогічний досвід; визначати ефективність власної діяльності. Особистіснозорієнтована взаємодія $з$ дитиною та їі батьками вимагає від вихователя здатності до моральновольової саморегуляції: уміння усвідомлювати свої почуття і контролювати їх прояви у виховних ситуаціях; виявляти тактовність і толерантність у взаємодії з дітьми і батьками; співвідносити власні мотиви і потреби з потребами дитини та дорослих [3]. Особистісна орієнтація вихователя визначає його готовність до аналітичної діяльності. Саме усвідомлення власних успіхів, досягнень, труднощів, інтересів і потреб дозволяє вихователям узагальнювати власний досвід роботи, обирати ефективні форми самовдосконалення і самоосвіти, максимально використовуючи власний педагогічний потенціал в освітньому процесі дошкільного закладу. Здатність вихователя до самоаналізуі діагностики різних сторін педагогічного процесу разом із чіткими уявленнями про власну роль у розвитку $\mathrm{i}$ вихованні дітей $є$ основою формування почуття відповідальності за якість процесу виховання. Саме ця властивість особистості стає рушійною силою підвищення його професійної компетентності. Також на розвиток у вихователів здатності до аналізу і самоаналізу впливає їхнє особистісне i професійне зростання; на формування почуття відповідальності значно впливає характер взаємодії вихователів із батьками вихованців, які, 3 одного боку, $є$ безпосередніми замовниками освітніх послуг, а 3 іншого - володіють певним педагогічним потенціалом і здатні збагачувати педагогічний процес позитивним досвідом сімейного виховання [4]. Особистісна спрямованість вихователів на взаємодію з батьками сприяє формуванню співпраці, єдності інтересів і потреб обох сторін, забезпечує наступність у вихованні в сім'ї і закладі освіти. Особистісно-зорієнтована взаємодія і відповідальність педагогів за якість процесу формування здорової особистості дитини дошкільника дозволяє найбільш повно забезпечити їхні освітні потреби, а також потреби батьків, педагогів, підвищити ефективність діяльності кожного педагога зокрема і якість виховного процесу в цілому [2].

В основу реалізації другої педагогічної умови - вироблення у вихованців навичок здоров'язбережувальної поведінки на основі формування у них позитивного ставлення до їі норм і правил, що визначає їхню життєву позицію у взаємодії з довкіллям - взято положення про те, що однією з причин відхилень у стані здоров'я $\epsilon$ неправильний спосіб життя, стан здоров'я дитини дошкільного віку найбільше погіршують такі фактори: гіпокінезія (дефіцит рухової активності), незбалансоване харчування, суттєве зростання інтелектуального навантаження і значний обсяг шкідливої інформації, скорочення часу перебування дитини на свіжому повітрі, порушення біологічних ритмів, збіднене сенсорне середовище, вплив лікарських препаратів, комп'ютерних технологій навчання і комп'ютерних ігор.

Тому процес виховання здоров'ябережувальної поведінки дітей потребує формування відповідальності усіх дорослих за рівень фізичного розвитку, стану здоров'я і формування культури здорового способу життя і науково-методичного підходу до педагогічного процесу, що передбачає:

- дотримання вимог Базового компонента дошкільної освіти і державних програм виховання і навчання дітей дошкільного віку;

- створення стійкої мотивації у дітей до постійного дотримання норм і правил здоров’ ябережувальної поведінки та контролю над власною активністю щодо її виконання; 

У ПРОЦЕСІ ВЗАЕМОДІЇ ЗАКЛАДУ ДОШКІЛЬНОЇ ОСВІТИ І СІМ'Ї

- визначення мети до кожної серії занять спільно з дошкільниками;

- створення і накопичення в дитячому колективі традицій і звичаїв здоров'ябережувальної поведінки, яка базується на традиціях українського народу;

- формування асоціативних зв'язків 3 поняттями і символами здоров'ябережувальної поведінки (схеми, екран настрою, малюнки), що впливає на позитивну мотивацію до здоров'ябережувальної діяльності;

- формування у дошкільників елементарних анатомічних і гігієнічних знань, виявлення через практику значущості дотримання режиму дня, оптимальної рухової активності, гарного настрою тощо;

- профілактика шкідливих звичок у дітей;

- підвищення психоемоційної стійкості;

- використання у педагогічному процесі традиційних і нетрадиційних форм здоров'ябережувальної спрямованості;

- постійний контроль за змінами у здоров'ябережувальній поведінці дитини і заохочення позитивних поведінкових проявів [4].

У сучасних умовах ціла низка дослідників (Т. Андрющенко, С. Бабюк, С. Кулачківська) акцентують увагу на необхідності враховувати такі основоположні принципи, які впливають на характер взаємодії батьків із вихователями закладу дошкільної освіти: сприймання вихователями батьків як соціальних замовників; настанова на безоцінне спілкування між цими значущими дорослими та постійний конструктивний діалог між ними; надання пріоритетності проблемі збереження та зміцнення здоров'я дітей; активізація і врахування особистісного досвіду батьків; варіативність змісту, форм і методів педагогічної підтримки батьків 3 питань формування здорової особистості дитини дошкільника. Отже, компетентний педагог має організувати таку взаємодію з батьками, для якої характерні різні іiі види, методи і прийоми активізації батьків щодо формування здорового способу життя дітей, урахування психологічного клімату сім’ї і досвіду сімейного виховання та забезпечення взаєморозуміння з кожною сім'єю загалом, а особливо 3 сім'ями 3 незадовільною здоров' язбережувальною ситуацією.

При цьому серед переваг оптимізації взаємодії вихователів із батьками дітей виокремлюємо такі: безпосередні щоденні контакти, можливість надавати адресну допомогу кожній конкретній сім'ї, враховуючи іiі здоров'язбережувальну виховну ситуацію; наявність зворотного зв'язку між вихователями і батьками; реальна, а не формальна допомога батькам у формування здорової особистості дитини з урахуванням особливостей фізичного і психічного розвитку кожної дитини. Спеціалісти в галузі психологопедагогічного консультування батьків виокремлюють такі специфічні особистісні риси та психологічні проблеми батьків, які можуть ускладнювати процес взаємодії 3 ними, а саме: нездатність взаємодіяти, неуважність, тривожність, агресивність, егоцентризм, авторитаризм, особистісна незрілість, дратівливість. Багатьом сучасним батькам притаманні установки, які істотно впливають на процес взаємодії з родиною: неадекватне оцінювання себе та своєї дитини, відсутність активно батьківської позиції, неадекватні виховні установки та погляди, некомпетентність батьків у питаннях вікових норм психічного та фізичного розвитку дітей [3].

Ефективність вибору форм взаємодії 3 батьками залежить від урахування індивідуальних відмінностей кожної сім’ї, сімейних традицій, соціального стану, житлових умов, інтересів сім'і у питаннях зміцнення здоров'я дітей. Вибрані вихователями і батьками форми оптимальної взаємодії ефективні лише в тому випадку, якщо вдається знайти ефективний стиль взаємодії вихователя 3 кожною сім'єю. Помилкові підходи батьків до формування здорової особистості дитини, труднощі батьків у взаємодії з дитиною та вихователями обумовлюються їхньою недостатньою обізнаністю та непоінформованістю щодо проблем виховання дітей дошкільного віку, їхніх психологічних та фізіологічних особливостей. Такі батьки не уважні до внутрішнього світу дитини, відчувають труднощі у вихованні і допускають помилки, які можуть вплинути на життя дитини та іiї здоров’я.

Оптимізація взаємодії сім’ї і закладу дошкільної освіти здійснювалася на засадах певних ресурсів взаємодії, серед яких: комунікативний ресурс взаємодії, що передбачав встановлення партнерських взаємин адміністрації дошкільного навчального закладу, спеціалістів вихователів, батьків і дітей на суб'єкт-суб'єктній основі. Орієнтація взаємодії в дошкільній установі на особистість дитини обумовлює необхідність встановлення суб'єкт-суб'єктних взаємин між учасниками педагогічного процесу. При цьому завідувач через використання непрямих колегіальних методів і методів стимулювання демократизує стиль взаємин у колективі та підвищує відповідальність усіх його членів формування здорової особистості дитини дошкільника. 


\section{ПЕДАГОГІЧНІ УМОВИ ФОРМУВАННЯЗДОРОВОЇ ОСОБИСТОСТІ ДИТИНИ ДОШКІЛЬНИКА У ПРОЦЕСІ ВЗАЄМОДІЇ ЗАКЛАДУ ДОШКІЛЬНОЇ ОСВІТИІ СІМ'Ї}

Змістово-організаційний ресурс взаємодії забезпечує створення умов для взаємодії суб'єктів педагогічного процесу і сприятливого емоційно-психологічного клімату в колективі; надання допомоги в організації різних форм роботи з вихователями, батьками і дітьми.

Аналітико-результативний ресурс взаємодії містить контроль за виконанням наміченої взаємодії, оперативне управління іiі реалізації, практичну діяльність адміністрації закладу дошкільної освіти 3 регулювання основних аспектів діяльності колективу. Окрім цього цей чинник вимагає аналізу й узагальнення отриманих результатів: співставлення досягнутих результатів із раніше запланованими, виявлення невирішених питань і недоліків у процесі реалізації діяльності колективу.

Формуванню активної позиції батьків у формування здорової особистості дитини сприяють такі особливості педагогічного процесу: доступність інформації про діяльність дошкільного закладу стосовно фізичного виховання дітей; різнопланові соціокультурні зв'язки з соціумом (фізкультурні майданчики, стадіон, басейн, парки тощо); урахування потреб різних типів сімей з різною здоров'язбережувальною виховною ситуацією та конкретних дітей і батьків при наданні освітніх послуг; спрямованість педагогів і адміністрації закладу дошкільної освіти на підвищення педагогічної культури батьків, вивчення досвіду сімейного виховання i використання його елементів в освітньому процесі, спрямованому на виховання здоров'ябережувальної поведінки дітей; використання педагогамиспеціальних методів набуття вмінь і навичок здоров'ябережувальної поведінки [6].

Задля оптимізації взаємодії з батьками із питань формування здорової особистості дитини дошкільника важливими є форми роботи спрямовані на колективну співпрацю (семінари, спільні свята й інші види дозвілля, консультації); індивідуальні форми співпраці (анкетування, бесіди, домашні завдання, наочно-інформаційну співпрацю (стенди, пам'ятки для батьків, тощо); активну участь батьків у педагогічному процесі закладу (спільні свята, розваги, змагання). Ці форми роботи з батьками оптимальні, якщо враховано індивідуальні відмінності кожної сім'ї, сімейні традиції, інтереси сім'ї в питаннях зміцнення здоров'я дітей.

Отже, визначені педагогічні умови дозволять більш ефективно здійснювати процес формування здорової особистості дитини дошкільника на засадах взаємодії з сім'єю.
Висновок. Обгрунтовано педагогічні умови формування здорової особистості дитини дошкільного віку у взаємодії закладу дошкільної освіти і сім’ї: підвищення компетентності вихователів щодо формування здорової особистості дитини; вироблення у вихованців навичок здоров'язбережувальної поведінки на основі формування у них позитивного ставлення до іiі норм і правил, що визначає їхню життєву позицію у взаємодії з довкіллям.

Визначено, що ці форми роботи з батьками оптимальні, якщо враховано індивідуальні відмінності кожної сім’ї, сімейні традиції, інтереси сім’ї в питаннях зміцнення здоров'я дітей.

\section{ЛІТЕРАТУРА}

1. Андрющенко Т. К. Організація освітнього процесу 3 формування у дошкільників здоров'язбережувальної компетентності / Т. К. Андрющенко // Науковий вісник. - ПНПУ ім. К. Д. Ушинського: зб. наук. пр. - Одеса, 2014. - Спецвипуск “Актуальні проблеми сучасної дошкільної та вищої освіти”. - С. 3 - 11 .

2. Бабюк Т. Й. Методи формування здорового способу життя в роботі зі старшими дошкільниками / Т. Й. Бабюк // Зб. наук. пр. Кам'янець-Подільського держ. ун-ту. Серія: Педагогічна. - Кам'янець-Подільський: ПП Мошак M.I., 2007. - Вип. 13. - Кн.2. - С.138 142.

3. Левінець Н. В.Впровадження здоров'язберігаючих технологійякактуальний напрям сучасної дошкільної освіти / Н. В. Левінець // Вісник Інститугу розвитку дитини: зб. наук. пр. Вип.16. - К.: Вид. НПУ ім. Н.П. Драгоманова, 2001. - С. 116 - 120.

4. Лісневська Н. В. Здоров'язберігаючі технології у фізичному вихованні дітей дошкільного віку / Н. В. Лісневська // Вісник Луганського національного університету імені Т.Шевченка: Педагогічні науки. - № 5 (264). - Ч. 2. - Луганськ, 2013. - С. 149d155.

5. Сварковська Л. А. Чинники формування здоров'я та фізичного стану вихованців дошкільних закладів / Л. А. Сварковська // Педагогічні науки: теорія, історія, інноваційні технології: [наук. журнал]. - Суми: СумДПУ ім. А.Макаренка, 2010. -№ 1(3). - С. 323-330.

6. Семенова Н. І. Педагогічні технології взаємодії дошкільного навчального закладу і сім’і у формуванні здорової особистості дошкільника / Н. І. Семенова // Наук. зап. Вінницького держ. пед ун-ту ім. М. Коцюбинського: зб. наук. пр. Серія: Педагогіка і психологія. - Вінниця, Планер, 2009. - Вип.27. - С. $384-388$.

7. Філоненко О. Здоровий випускник дитсадка 


\section{ПЕДАГОГІЧНІ УМОВИ ФОРМУВАННЯЗДОРОВОЇ ОСОБИСТОСТІ ДИТИНИ ДОШКІЛЬНИКА У ПРОЦЕСІ ВЗАЕМОДІЇ ЗАКЛАДУ ДОШКІЛЬНОЇ ОСВІТИ І СІМ'Ї}

- успішний школярик /О. Філоненко // Дошкільне виховання. -2014 . - № 5. - С. $17-19$.

8. Юрочкіна С. О. Педагогічні засади валеологічного виховання дітей старшого дошкільного віку: автореф. канд. пед. наук: 13.00.01 / С. О. Юрочкіна. - К., 1997. - 153 с.

\section{REFERENCES}

1. Andriushchenko, T. K. (2014). Orhanizatsiia osvitnoho protsesu $\mathrm{z}$ formuvannia $\mathrm{u}$ doshkilnykiv zdoroviazberezhuvalnoi kompetentnosti [The organization of the educational process on the formation of preschoolers' healthcare-saving competence]. Scientific Herald. Southern Ukrainian Kostyantyn Ushynskiy National Pedagogical University: a collection of scientific works. Odesa, pp. 3 - 11.[in Ukrainian].

2. Babiuk, T. Y. (2007). Metody formuvannia zdorovoho sposobu zhyttia $\mathrm{v}$ roboti zi starshymy doshkilnykamy [The methods of forming a healthy lifestyle while working with older preschoolers]. A collection of scientific works of KamyanetsPodilskiy State University. Series: Pedagogical. Kamianets-Podilskyi: PP Moshak M.I., vol. 13, book 2, pp. 138 - 142. [in Ukrainian].

3. Levinets, N. V. (2001). Vprovadzhennia zdoroviazberihaiuchykh tekhnolohii yakaktualnyi napriam suchasnoi doshkshlinoi osvity [An introduction of health-saving technologies as an actual trend of modern preschool education]. Bulletin of the Institute of Development of Child: a collection of scientific works, vol.16, Kyiv: Vyd. NPU im. N.P. Drahomanova, pp. 116 - 120. [in Ukrainian].

4. Lisnevska, N. V. (2013). Zdoroviazberihaiuchi tekhnolohii u fizychnomu vykhovanni ditei doshkilnoho viku [The health-saving technologies of the physical education of children of preschool age.]. Herald of Luhansk Taras Shevchenko National University.: Pedagogical sciences, no.5 (264), part. 2, Luhansk, pp.149 - 155. [in Ukrainian].

5. Svarkovska, L. A. (2010). Chynnyky formuvannia zdorovia ta fizychnoho stanu vykhovantsiv doshkilnykh zakladiv [The factors of formation of health and physical condition of pupils of preschool establishments]. Pedagogical sciences: theory, history, and innovative technologies. Sumy: Sum DPU im. A.Makarenka, no.1(3), pp. 323-330. [in Ukrainian].

6. Semenova, N. I. (2009). Pedahohichni tekhnolohii vzaiemodii doshkilnoho navchalnoho zaklidu i simi u formuvannia zdorovoi osobystosti doshkilnyka [The pedagogical technologies of interaction between the preschool educational institution and the family in formation of healthy personality of preschooler]. Scientific notes of Vinnytsya Mukhaylo Kotsyubynskiy State Pedagogical University.: a collection of scientific works.Vinnytsia, Planer, vol.27, pp. $384-388$. [in Ukrainian].

7. Filonenko, O. (2014). Zdorovyi vypusknyk dytsadka - uspishnyi shkoliaryk [A healthy graduate of kindergarten is a successful student]. Preschool education, no. 5, pp.17 - 19. [in Ukrainian].

8. Yurochkina, S. O. (1997). Pedahohichni zasady valeolohichnoho vykhovannia ditei starshoho doshkilnoho viku [The pedagogical bases of the valeological education of children of the senior preschool age]. Extended abstract of candidate's thesis. Kyiv, 153 p. [in Ukrainian].

Стаття надійшла до редакції 06.07.2018

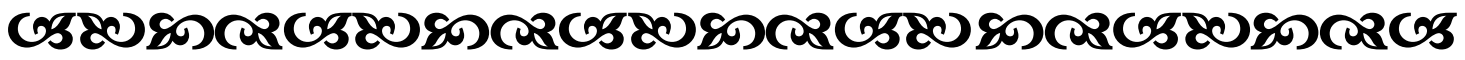

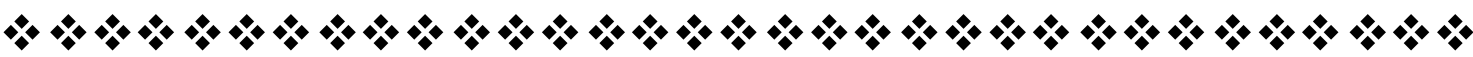

"Хто бажає, щоб народ був щасливий $і$ виховувався успішно, той повинен визнати якпериу і неминучу умову досягнення иієї мети - виховання $і$ освіту вчителів, а тақож тақе їхстановище, що відповідало б їхньому важливому обов'язку".

Адольб Dістервег

німеиький педагог-демоқрат

"Усе своє Життя старанно навчайся. Кожен день ставай майстернішим, ніж ти був за день до иъого, а на наступний день - майстернішим, ніж сьогодні. Вдосконалення не має кіния".

Яммамото भуунетомо білософ, письменник

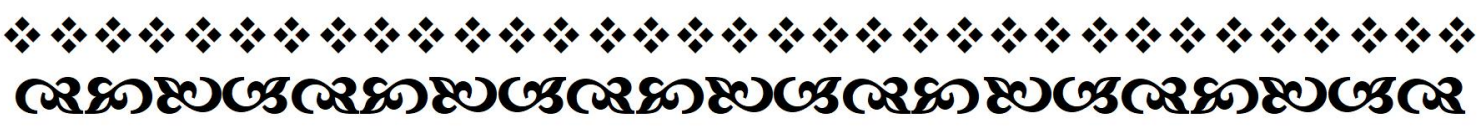

